\title{
Small dams alter thermal regimes of downstream water
}

\author{
André Chandesris ${ }^{1}$, Kris Van Looy ${ }^{2}$, Jacob S. Diamond ${ }^{1,3}$, and Yves Souchon ${ }^{1}$ \\ ${ }^{1}$ River Hydro-Ecology Lab, National Research Institute of Science and Technology for Environment and Agriculture, \\ UR Riverly, Lyon, France \\ ${ }^{2}$ OVAM, Stationsstraat 110, 2800 Mechelen, Belgium \\ ${ }^{3}$ Université de Tours, E.A 6293 GéoHydrosytèmes COntinentaux, Parc de Grandmont, 37200 Tours, France
}

Correspondence: André Chandesris (andre.chandesris@irstea.fr)

Received: 28 March 2019 - Discussion started: 9 April 2019

Revised: 27 September 2019 - Accepted: 3 October 2019 - Published: 5 November 2019

\begin{abstract}
The purpose of this study was to quantify the downstream impacts of different types of small dams on summer water temperature in lowland streams. We examined (1) temperature regimes upstream and downstream of dams with different structural characteristics, (2) relationships between stream temperature anomalies and climatic variables, watershed area, dam height, impoundment length and surface area, and residence time, (3) the most significant variables explaining the different thermal behaviors, and (4) the dam thermal effect considering a biological threshold of $22^{\circ} \mathrm{C}$, with a calculation of both the number of days with a temperature above this threshold and the average hourly duration above this threshold.

Water temperature loggers were installed upstream and downstream of 11 dams in the Bresse region (France) and monitored at $30 \mathrm{~min}$ intervals during summer (June to September) over the 2009-2016 period, resulting in 13 paired water temperature time series (two sites were monitored for two summers, allowing the opportunity to compare cold and hot summers).

At $23 \%$ of the dams, we observed increased downstream maximum daily temperatures of more than $1^{\circ} \mathrm{C}$; at the remaining dams we observed changes in the maximum daily temperature of -1 to $1^{\circ} \mathrm{C}$. Across sites, the mean downstream increase of the minimum daily temperature was $1^{\circ} \mathrm{C}$, and for $85 \%$ of the sites this increase was higher than $0.5^{\circ} \mathrm{C}$.

We hierarchically clustered the sites based on three temperature anomaly variables: upstream-downstream differences in (1) maximum daily temperature $\left(\Delta T_{\max }\right)$, (2) minimum daily temperature $\left(\Delta T_{\min }\right)$, and (3) daily temperature amplitude $\left(\Delta T_{\mathrm{amp}}\right)$. The cluster analysis identified two main types of dam effects on thermal regime: (1) a downstream
\end{abstract}

increase in $T_{\min }$ associated with $T_{\max }$ either unchanged or slightly reduced for impoundments of low volume (i.e., a residence time shorter than $0.7 \mathrm{~d}$ and a surface area less than $35000 \mathrm{~m}^{2}$ ), and (2) a downstream increase of both $T_{\min }$ and $T_{\max }$ of the same order of magnitude for impoundments of larger volume (i.e., a residence time longer than $0.7 \mathrm{~d}$ and a surface area greater than $35000 \mathrm{~m}^{2}$ ). These downstream temperature increases reached $2.4^{\circ} \mathrm{C}$ at certain structures with the potential to impair the structure of aquatic communities and the functioning of the aquatic ecosystem.

Overall, we show that small dams can meaningfully alter the thermal regimes of flowing waters, and that these that these effects can be explained with sufficient accuracy $\left(R^{2}=0.7\right)$ using two simple measurements of small dam physical attributes. This finding may have importance for modelers and managers who desire to understand and restore the fragmented thermalscapes of river networks.

\section{Introduction}

\subsection{Temperature is a master physical variable in streams}

Water temperature governs the geographical range, condition, and physiology of aquatic organisms (Allan and Castillo, 2007), with coincident influence on stream metabolism (Bernhardt et al., 2018; Brown et al., 2004). For example, as ectotherms, aquatic organisms are very sensitive to ambient water temperature and to its alteration, especially near their upper thermal temperature tolerance (Brett and Groves, 1979; Coutant, 1987; McCullough et al., 2009 
for a review on cold-water fish; Souchon and Tissot, 2012 for a review on European non-salmonid fish). Water temperature also governs the life history of invertebrates by affecting egg development, fecundity, dormancy, growth, maturation, voltinism, and emergence (Rader et al., 2007). Therefore, understanding the river thermal regime is crucial to understanding ecological functioning (Hester et al., 2009), particularly in an era of global warming (IPCC, 2007, 2013) and numerous ecological changes (Woodward et al., 2010).

\subsection{Drivers of water temperature}

Major natural drivers of water temperature are (1) climate, i.e., solar radiation, air temperature, wind, precipitation, upstream water temperature, (2) topography, i.e., stream orientation, stream shading by surrounding vegetation, (3) stream bed characteristics, i.e., hyporheic exchanges, groundwater input, and (4) stream discharge (Caissie, 2006). These governing physical variables can be used to identify the primary environmental determinants of a thermal regime for a given site (Caissie, 2006; Hannah et al., 2004; Kelleher et al., 2012; Mohseni et al., 1998; Webb et al., 2008). During summer, which is a particularly sensitive time for aquatic organisms, the factors leading to stream warming are (1) the input of heat fluxes from upstream (depending on discharge and water temperature), (2) direct and indirect solar radiation dominated by infrared radiation, (3) air-water conduction (convective heat flux or sensible heat), and (4) stream bed conduction. The factors leading to cooling are (1) longwave radiation emitted by the water surface, (2) latent heat, and (3) the influx of groundwater. Importantly, the stream thermal regime may also be influenced by anthropogenic structures, with point-scale effects in the case of dams, or more spatially distributed effects in the case of riparian vegetation clearings. Hence, impacts can vary in spatial and temporal scope, depending on relative size effects of stream (headwater to river) versus human features (e.g., power plant reservoir volume; extent of vegetation clearings). Specifically, dams can modify stream thermal regimes by altering heat storage volumes, and by increasing the contact surface of a stream with the atmosphere.

\subsection{Large dam effects}

The Hester and Doyle (2011) literature review reveals that the cooling effect of large dams (above $15 \mathrm{~m}$ high), where water is released downstream from cooler hypolimnetic layers during stratified periods, is the most described worldwide. The serial discontinuity concept (SDC, Ward and Stanford, 1983) is largely based on this property of water cooling by large stratified impoundments. In the SDC framework, large dams can alter longitudinal downstream water temperature pattern for tens of kilometers depending on dam characteristics, flow regime, river physical characteristics, and downstream inputs of lakes, groundwater, and tributaries (Olden and Naiman, 2010; Ellis and Jones, 2013 for a review). In addition, Ward and Stanford (1983) suggest that dams in headwaters may not alter the natural temperature range, with the assumption that canopy shading, and springs or groundwater influx can buffer annual temperature variations. However, this view may be incomplete, as downstream warming may occur during summer releases from small surface reservoirs (O’Keeffe et al., 1990).

\subsection{Small dam characteristics are not well established}

Although much is known regarding thermal effects of large dams, less is known about the impacts of small dams because their spatial distribution and physical characteristics are not well established. This is especially true for run-ofthe-river dams (RRDs) with little or no thermal stratification and the absence of surface releases (Cumming, 2004; Hayes et al., 2008). Due to the increased surface of the impoundment exposed to solar radiation and decreased flow velocity, RRDs are expected to increase downstream water temperatures, contrary to large dams with cold hypolimnion release. These small dams have been built over many years for a variety of uses (e.g., mills, irrigation, livestock watering, storm water management, aesthetic lakes, hydroelectricity, and stream stabilization). Moreover, in contrast to large dams, the number, spatial location, and characteristics of small dams are not well known or are often very imprecise depending on national databases. The International Commission of Large Dams (ICOLD, 2017) inventoried 59071 large dams (i.e., a height of $\geq 15 \mathrm{~m}$ or a height of 5-15 m impounding more than $3 \times 10^{6} \mathrm{~m}^{3}$ ) in 160 countries, but the number of smaller dams could be several million worldwide. In France alone, the Referentiel des Obstacles à l'Ecoulement des Eaux (the national inventory of dams and weirs) database maintained by the French Biodiversity Agency inventoried 96222 hydraulics works crossing streams and rivers as of September 2017. This corresponds to a density of 0.42 obstacles per kilometer on a basis of $230000 \mathrm{~km}$ streams with permanent flow. However, the complete characteristics of these hydraulic works are not yet quantified, and it is important to note that height alone is not sufficient to discriminate their environmental effects (Poff and Hart, 2002). Mbaka and Mwaniki (2015) proposed definitions for the different features, considering RRDs as impoundments with heights not exceeding the river bank elevation, small weirs (SW) corresponding to heights of around $5 \mathrm{~m}$, and low-head dams (LHD) with heights of between 5 and $15 \mathrm{~m}$. In this work, we studied dams with a height of less than $5 \mathrm{~m}$, which we hereafter refer to as small dams.

\subsection{Small dam thermal effects}

In their review, Hester and Doyle (2011) concluded that most typical human impacts including small dams alter stream or river temperatures by $5^{\circ} \mathrm{C}$ or less. Mbaka and 
Mwaniki (2015), in their global review of the downstream effect of small impoundments, found that out of 43 studies, $25 \%$ reported a temperature increase effect, $2 \%$ noted a decrease effect, and $73 \%$ observed no change. Dripps and Granger (2013) studied the influence of three residential artificial headwater lakes (17-45 ha) on stream (discharge $=0.0024-0.0109 \mathrm{~m}^{3} \mathrm{~s}^{-1}$ ) thermal regimes. They measured a summer downstream temperature increase of as much as $8.4{ }^{\circ} \mathrm{C}$ and a decrease of diurnal variability of as much as $3.9^{\circ} \mathrm{C}$. Maxted et al. (2005) found that impoundments (height $<5 \mathrm{~m}$ and surface area $<1 \mathrm{ha}$ ) in rural catchments increased downstream mean daily stream temperatures by $3.1-6.6^{\circ} \mathrm{C}$ during the critical summer period, and temperature differences were 3 times higher than those in woody catchments $\left(0.8-2.0^{\circ} \mathrm{C}\right)$. In the Laurentian Great Lakes region, Hayes et al. (2008) studied two types of dams with different uses. They measured a weak to no existent thermal effect of low-head barriers (height $<0.5 \mathrm{~m}$ ) built to prevent the upstream migration of sea lamprey (Petromyzon marinus, L.). Conversely, they measured a greater effect for small hydroelectric dams (downstream temperature increases of up to $5.6^{\circ} \mathrm{C}$ ). Analyzing the thermal effects of beaver dams, Weber et al. (2017) found a complex and diverse range of temperature responses. Similarly, some authors find little to no thermal influence of beaver dams (Sigourney et al., 2006), and others find extreme temperature increases of up to $7{ }^{\circ} \mathrm{C}$ in a headwater passing through large ( $5 \mathrm{ha}$ ) beaver dam complexes (Margolis et al., 2001).

These studies illustrate the large variability in the downstream responses to small dams, and the difficulty in identifying the explanatory variables governing these responses, with dam height alone being a poor predictor. Nevertheless, several explanatory variables are clearly relevant, including stream size, stream order, watershed surface and vegetation cover, climate context, geology and alluvial aquifers, groundwater exchange, impoundment surface directly submitted to radiation, water residence time, and base flow discharge. Variability in the downstream responses appears to be greater in headwaters due to the weak thermal inertia and great diversity of these waterbodies, especially with regard to local shading effects from riparian canopy cover and the relative importance of spring or tributary discharges.

\subsection{Objective of the study}

The purpose of this study was to quantify the downstream impacts of different types of small dams on the summer water temperature in lowland streams. We chose to examine the summer period because this is when stream temperatures reach maximum annual values with the corresponding highest probability of reducing ecological functioning. We examined the following: (1) temperature regimes upstream and downstream of dams with different structural characteristics, (2) relationships between upstream-downstream stream temperature anomalies and climatic variables, watershed charac- teristics, and dam hydraulic geometry, (3) the most significant variables explaining the different thermal behaviors, in order to account for dam diversity and functioning in future climate, and (4) the dam thermal effect considering a biological threshold of $22^{\circ} \mathrm{C}$, with a calculation of both the number of days with a temperature above this threshold and the average hourly duration above this threshold.

\section{Methods}

\subsection{Study area}

Our study area is an alluvial lowland plain northeast of Lyon, France, between the Jura and the northern Massif Central mountain ranges (Fig. 1), at altitudes of between 170 and $320 \mathrm{~m}$. The main river in our study area is the Saone, which has a network of tributaries (Strahler orders 1-5) drained primarily by agricultural $(67.4 \%$; French average $=59.5 \%)$ and urban land cover $(7.2 \%$; French average $=5.5 \%)($ UE-SOeS, CORINE Land Cover, available at: https://www.data.gouv.fr/fr/datasets/ corine-land-cover-occupation-des-sols-en-france/, last access: June 2019), characteristic of temperate European plain regions. The dam and weir density is 0.64 features per kilometer, which is $50 \%$ greater than the French average of 0.42 features per kilometer for streams with permanent flow. The density of the stream network is comparable with that of the national average $\left(0.4 \mathrm{~km} \mathrm{~km}^{-2}\right)$.

The climate in our study area is cold continental, characterized by hot, dry summers (average maximum temperature of $25.8^{\circ} \mathrm{C}$ ) and cold winters (average maximum temperature of $5{ }^{\circ} \mathrm{C}$ ). The average annual precipitation for the region is $900 \mathrm{~mm}$. This region is distinguished climatically by maximum median air temperatures in July (1960-1990 period) exceeding $25.5^{\circ} \mathrm{C}$, which is equivalent to those of the Mediterranean region and of southwest France (Wasson et al., 2002). Regionalized climate projections on the scale of France (Peings et al., 2012) indicated that this region is susceptible to higher summer air temperatures, with increases of $2-3{ }^{\circ} \mathrm{C}$ for maximum daily temperatures. For scenario A1B (mean concentration of greenhouse gases), the estimation was more than 10 additional days of heat waves (as defined by WMO, 1966) by 2050 .

\subsection{Sampling sites}

The 11 dams in the study area are overflow structures that occupy the sites of former water mills, some of which still produce energy. The study dams had heights between 1.0 and $2.4 \mathrm{~m}$, with backwater flow lengths from 280 to $2950 \mathrm{~m}$, and impoundment volumes from 1200 to $53000 \mathrm{~m}^{3}$. We calculated the average residence time (in days, d) as the ratio of the impoundment volume $\left(\mathrm{m}^{3}\right)$ to the daily water flow volume $\left(\mathrm{m}^{3} \mathrm{~d}^{-1}\right)$. The daily water flow volume is estimated from nearby hydrometric measurement sites 


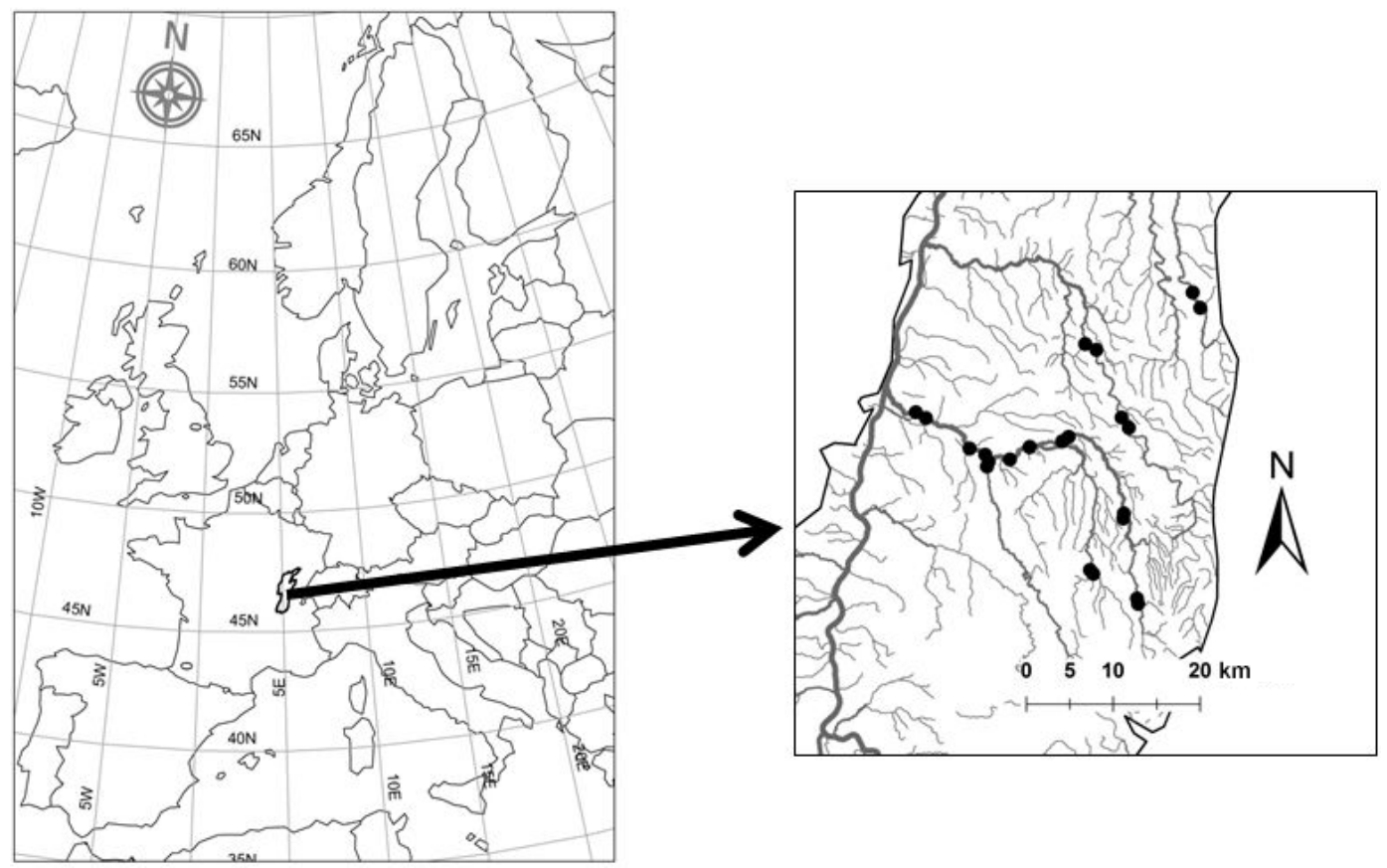

Figure 1. Location of the study area, the Bresse region - the black points on the right map indicate temperature recording sites.

(French database HYDRO) that are weighted by a correction coefficient during low flow periods. The correction coefficient is estimated from synoptic gauging performed by the regional hydrometric institute (Direction Regionale de l'Environnement, de l'Amenagement et du Logement, DREAL, 2018). Average residence times at our dams vary from 0.1 to $8.4 \mathrm{~d}$ (Table 1).

The structures studied differ considerably in impoundment surface area, residence time, and their position in the hydrographic network (Table 1). These variables govern (1) the input of diurnal heat from solar radiation, (2) the loss of nocturnal heat linked to evaporation and emitted longwave radiation, and (3) the upstream permanent inflow of heat.

\subsection{Temperature monitoring}

The temperature sampling was performed in summer (from the end of June to the beginning of September) in different years (from 2009 to 2016) by the local water management organization (Syndicat Mixte Veyle Vivante). For two sites, we have data for two different summers (Champagne in 2009 and 2015 and Fretaz in 2014 and 2016) because the local water management organization was particularly interested in the thermal regimes of these rivers (Table 1).

We installed temperature sensors $\left(\right.$ Hobo $^{\circledR}$ Pendant, Onset Computer Application; accuracy $\pm 0.54^{\circ} \mathrm{C}$ ) upstream and downstream of each dam. Upstream sensors were placed upstream of the backwater flow length of the dam, and downstream sensors were placed $<100 \mathrm{~m}$ downstream of the dam in the main flow channel. Both upstream and downstream sensors were placed at depths of $20-50 \mathrm{~cm}$. The temperature was recorded at a time step of $30 \mathrm{~min}$. The temperature sensors were calibrated each year using the simple "ice bucket" procedure introduced by Dunham et al. (2005).

The monitoring period had higher than normal air temperatures, except for 2014 (only one site), which was colder with significantly higher precipitation. Precipitation was normal throughout the study period, except in 2009 and 2016, which were lower than normal (Table 2). The summer climatic characteristics for our analysis period are compared with the normal values produced by Meteo France (1981-2010).

\subsection{Temperature data analysis}

To characterize the influence of dams on stream thermal regimes we first calculated three variables: daily difference between upstream and downstream temperature (1) maximums $\left(\Delta T_{\max }\right)$, (2) minimums $\left(\Delta T_{\min }\right)$, and (3) amplitudes $\left(\Delta T_{\mathrm{amp}}\right)$ for each site and year. With these data, we then conducted the following analyses:

1. median summer differences in $\Delta T_{\max }, \Delta T_{\min }$, and $\Delta T_{\text {amp }}$ (median is used instead of mean to limit the influence of extreme values);

2. regression between daily upstream and downstream water temperature to directly assess dam thermal effects;

3. regression between daily air and water temperature over the whole recording period to assess the influence of air temperature on observed relationships. 
Table 1. Physical characteristics of dams of the river and impoundments.

\begin{tabular}{llrrrrrrrrr}
\hline $\begin{array}{l}\text { Stream } \\
\text { name }\end{array}$ & Dam name & $\begin{array}{r}\text { Watershed } \\
\left(\mathrm{km}^{2}\right)\end{array}$ & $\begin{array}{c}\text { Distance } \\
\text { to the } \\
\text { source }(\mathrm{m})\end{array}$ & $\begin{array}{c}\text { Strahler } \\
\text { order }\end{array}$ & $\begin{array}{c}\text { Dam } \\
\text { height } \\
(\mathrm{m})\end{array}$ & $\begin{array}{r}\text { Length } \\
\text { (impoundment }) \\
(\mathrm{m})\end{array}$ & $\begin{array}{r}\text { Surface } \\
\left(\mathrm{m}^{2}\right)\end{array}$ & $\begin{array}{c}\text { Volume } \\
\left(\mathrm{m}^{3}\right)\end{array}$ & $\begin{array}{c}\text { Residence } \\
\text { time }(\mathrm{d})\end{array}$ & $\begin{array}{c}\text { Year of } \\
\text { sampling }\end{array}$ \\
\hline Veyle & Dompierre & 32 & 11167 & 3 & 1.2 & 500 & 10900 & 10500 & 8.4 & 2010 \\
\hline Veyle & Fretaz & 78 & 22859 & 4 & 1.5 & 535 & 3500 & 2600 & 0.1 \\
0.1 & 2014 \\
\hline Veyle & Montfalconnet & 125 & 38146 & 4 & 2.4 & 1200 & 14400 & 20160 & 0.5 & 2015 \\
\hline Veyle & Peroux & 500 & 50886 & 5 & 2.4 & 2150 & 39200 & 53000 & 0.6 & 2015 \\
\hline Veyle & Thuets & 350 & 43912 & 5 & 1.9 & 2950 & 57000 & 51000 & 0.6 & 2016 \\
\hline Veyle & Thurignat & 640 & 60537 & 5 & 1.4 & 1500 & 34600 & 31165 & 0.2 & 2016 \\
\hline Vieux Jonc & Cailloux & 67 & 11680 & 3 & 1.0 & 280 & 2340 & 1200 & 0.7 & 2009 \\
\hline Renon & Champagne & 122 & 42368 & 3 & 1.5 & 405 & 2840 & 2130 & 0.7 \\
\hline Reyssouze & Moulin Neuf & 209 & 48217 & 3 & 1.0 & 1800 & 35520 & 12420 & 0.3 \\
\hline Reyssouze & Peloux & 145 & 34842 & 3 & 1.5 & 1700 & 49930 & 17340 & 0.5 \\
\hline Solnan & Revel & 88 & 15431 & 3 & 1.8 & 3200 & 31140 & 28370 & 2.6 \\
\hline
\end{tabular}

Table 2. Climatic characteristics during years of stream temperature monitoring (2009-2016).

\begin{tabular}{lrr}
\hline $\begin{array}{l}\text { Year } \\
\text { (July- } \\
\text { August) }\end{array}$ & $\begin{array}{r}\text { Air } \\
\text { temperature } \\
\text { anomaly }\left({ }^{\circ} \mathrm{C}\right)\end{array}$ & $\begin{array}{r}\text { Precipitation } \\
\text { anomaly (\%) }\end{array}$ \\
\hline 2009 & +1.1 & 70 \\
2010 & +0.3 & 50 \\
$\mathbf{2 0 1 4}$ & $-\mathbf{1 . 8}$ & $\mathbf{1 6 5}$ \\
2015 & +2 & 50 \\
2016 & +0.3 & 70 \\
\hline
\end{tabular}

Source: https://www.infoclimat.fr (last access: June 2018) Lyon Bron station normal 1991-2015 * 2014 is bold to highlight the relatively large climate anomaly in this year.

To assess the potential biological importance of dam thermal effects, we also calculated (1) the number of days that maximum water temperatures were greater than $22^{\circ} \mathrm{C}$, and (2) the mean of the maximum daily duration (in hours, $\mathrm{h}$ ) where the water temperature was greater than $22^{\circ} \mathrm{C}$. We chose $22^{\circ} \mathrm{C}$ as an illustrative threshold, which is known to be a thermal stress benchmark value for salmonids (Elliott and Elliot, 2010; Ojanguren et al., 2001).

\subsection{Site typology analysis}

We observed different thermal regimes in our data and wanted to classify them. To do so, we carried out a hierarchical cluster analysis using Euclidian dissimilarities matrix according to the method of Ward Jr. (1963) using the daily dataset $(n=807)$ of $\Delta T_{\max }$ and $\Delta T_{\min }$ obtained over all time series. We forced the classification to integrate the different time-series effect by adding a complete disjunctive table differentiating each time series to the dataset. This procedure makes it possible to group the data first by time series, then in a second step to differentiate them from each other (i.e., to differentiate site thermal regimes).

\subsection{Ordination analysis}

To characterize the impacts of the different dams, a principal component analysis (PCA) was carried out using the XLSTAT (Addinsoft ${ }^{\mathrm{TM}}$ ) software on the three water temperature variables: $\Delta T_{\max }, \Delta T_{\min }$, and $\Delta T_{\mathrm{amp}}$. We used the median values for variables in each time series in order to build an input matrix (13 occurrences for three variables).

Then a complementary redundancy analysis (RDA) with an automatic stepwise variable selection procedure was used to identify the physical dam characteristics (Table 1) that significantly explain the PCA results (Ter Braak, 1986).

After the RDA identified the relevant physical dam characteristics, we conducted a multiple linear regression between these characteristics and temperature variables to determine the specific effect sizes of these characteristics on the thermal regime.

\section{Results}

\subsection{General temperature patterns}

Regardless of site or year, we observed a consistent pattern of summer temperature variations consisting of the following (Fig. 2): 

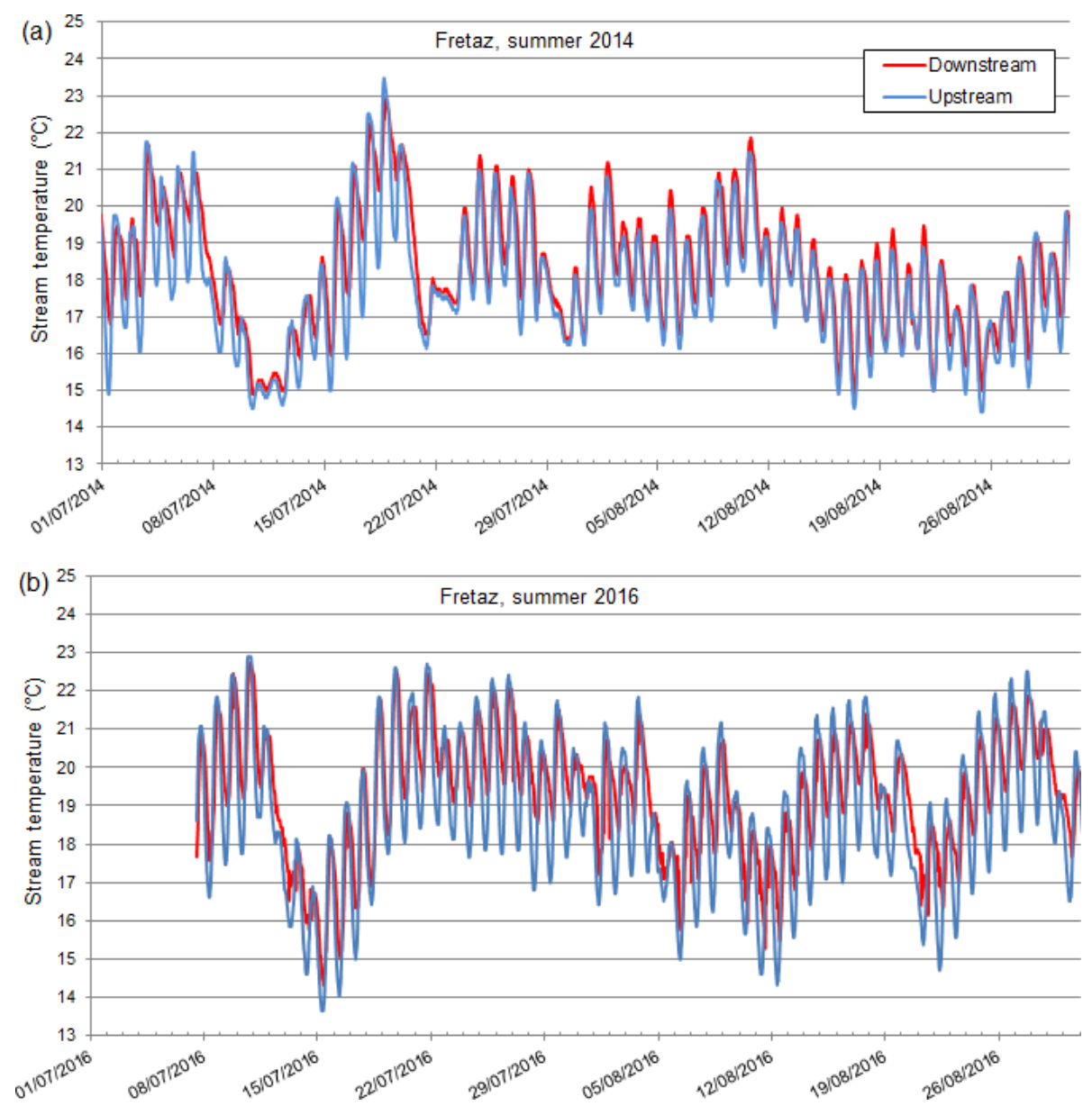

Figure 2. Time series of water temperature $\left({ }^{\circ} \mathrm{C}\right)$ upstream (blue) and downstream (red) of the Fretaz dam in the Veyle stream, respectively, in the years 2014 (a) and 2016 (b). These example sites are illustrative of the group A typology, where $T_{\min }$ is increased downstream but $T_{\max }$ is not.

- daily (diel) variation (minimum in early morning, maximum in late evening);

- periods of progressively increasing $T_{\min }$ and $T_{\max }$; and

- rapid drops in temperature that interrupt these periods, and that are generally linked to precipitation events.

The periods of progressively increasing temperature vary in length, magnitude, and timing from one year to another, but the general pattern remains the same, as demonstrated by the case of the Fretaz dam, monitored in 2014 (a cold and humid year) and 2016 (a more normal year, Fig. 2; Table 2).

We observed two consistent patterns in upstreamdownstream thermal regimes. In the first pattern, $T_{\min }$ is higher downstream, but $T_{\max }$ stays relatively constant (Fig. 2). We note that these upstream-downstream differences were muted in 2014, the cold and humid year (Fig. 2). This thermal pattern (i.e., where $T_{\min }$ increases downstream, but not $T_{\max }$ ) is observed in 7 out of 13 cases (Table 3 ). In the other cases ( 6 out of 13; Table 3 ), we observed a second pattern, where both $T_{\min }$ and $T_{\max }$ are higher downstream of the structure, which results in a consistent shift between the two temperature time series (Fig. 3, selected examples: Dompierre dam, 2010 and Peroux dam, 2015).

\subsection{Upstream-downstream differences}

The two dominant patterns of temperature differences are further illustrated by plotting downstream versus upstream $T_{\min }$ and $T_{\max }$ values at the site. For example, at Dompierre in 2010, we observed a consistent shift of approximately $+1.5^{\circ} \mathrm{C}$ (both $T_{\min }$ and $T_{\max }$ ) between the upstream and downstream areas with respect to the dam (Fig. 4a). In contrast, at Fretaz in 2014, this shift is dampened, and temperature values between the upstream and downstream regions more closely follow a $1: 1$ relationship (Fig. 4b).

We also observed that $\Delta T_{\mathrm{amp}}$ was reduced for $61.5 \%$ of our time series (Table 3). This reduction in amplitude is primarily due to a truncated daily minimum downstream tem- 

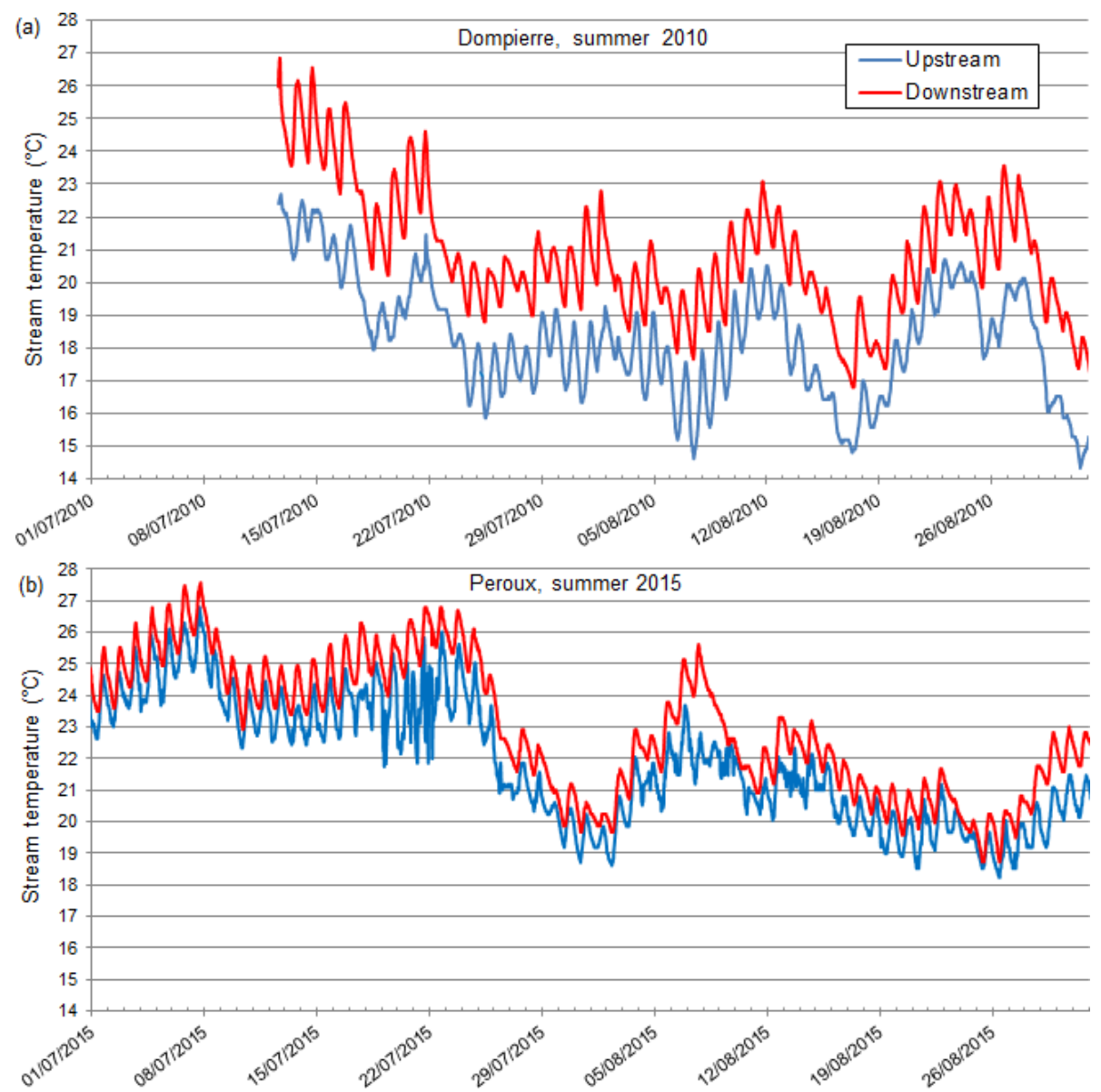

Figure 3. Time series of water temperatures upstream (blue line) and downstream (red line) of the (a) Dompierre and (b) Peroux dams in the Veyle stream ( 2010 and 2015 , two warm summer years, respectively, +1.1 and $2{ }^{\circ} \mathrm{C}$, Table 2 ). These example sites are illustrative of the group B typology, where both $T_{\min }$ and $T_{\max }$ are increased downstream.
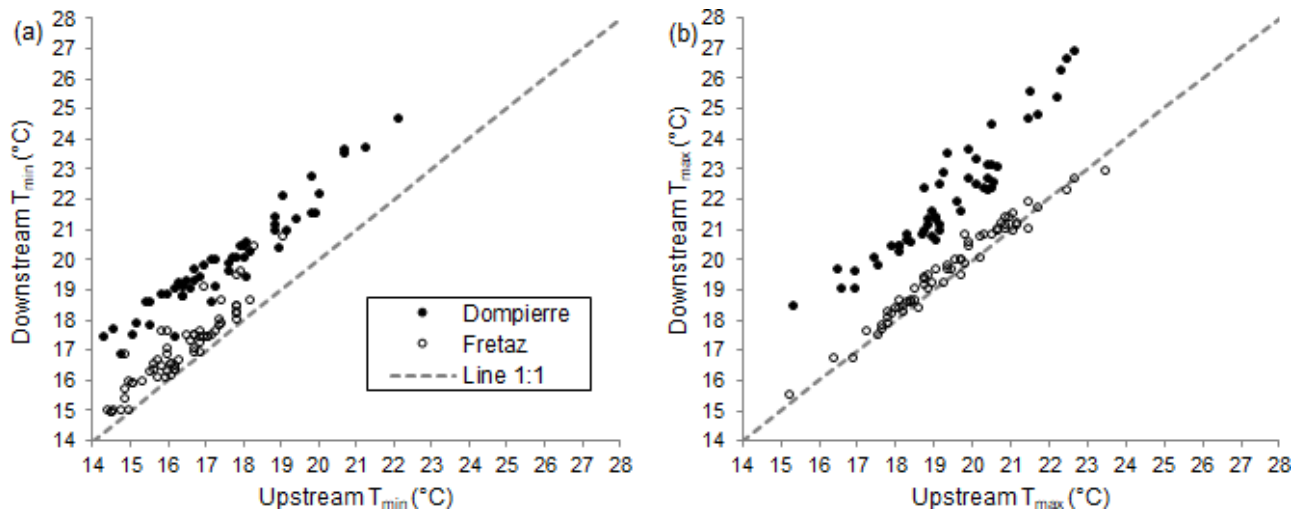

Figure 4. (a) Minimum and (b) maximum daily temperatures upstream and downstream of the run-of-the-river dams (Dompierre site, Veyle stream in 2010; Fretaz site, Veyle stream in 2014). The dashed line is the $1: 1$ line. 
Table 3. Median values of differences between daily maximum $\left(\Delta T_{\max }\right)$ and minimum temperatures $\left(\Delta T_{\min }\right)$ and the diurnal ranges $\left(\Delta T_{\text {amp }}\right)$ between upstream and downstream regions of the run-of-the-river dams. The daily maximum upstream temperature $\left(T_{\max }\right.$,up $)$ is indicated to show the limited influence of the initial temperature on upstream-downstream differences.

\begin{tabular}{llrrrr}
\hline Group & Run-of-the-river dam (stream) & $\begin{array}{r}\Delta T_{\max } \\
\left({ }^{\circ} \mathrm{C}\right)\end{array}$ & $\begin{array}{r}\Delta T_{\min } \\
\left({ }^{\circ} \mathrm{C}\right)\end{array}$ & $\begin{array}{r}\Delta T_{\text {amp }} \\
\left({ }^{\circ} \mathrm{C}\right)\end{array}$ & $\begin{array}{c}T_{\max , \text { up }} \\
\left({ }^{\circ} \mathrm{C}\right)\end{array}$ \\
\hline \multirow{4}{*}{ A } & Moulin Neuf (Reyssouze), 2016 & -0.6 & 0.5 & -1.0 & 24.0 \\
& Cailloux (Vieux Jonc), 2009 & -0.4 & 0.9 & -1.3 & 18.1 \\
& Fretaz (Veyle), 2014 & 0.3 & 0.7 & -0.3 & 19.4 \\
& Fretaz (Veyle), 2016 & -0.3 & 1.2 & -1.4 & 21.2 \\
& Champagne (Renon), 2015 & 0.1 & 0.9 & -0.9 & 20.2 \\
& Montfalconnet (Veyle), 2015 & -0.1 & 1.0 & -0.8 & 19.8 \\
& Champagne (Renon), 2009 & -0.1 & 0.7 & -1.0 & 19.3 \\
\hline \multirow{3}{*}{ B1 } & Thurignat (Veyle), 2016 & 0.6 & 0.3 & 0.4 & 23.2 \\
& Thuets (Veyle), 2016 & 0.7 & 0.8 & 0.0 & 21.0 \\
& Peloux (Reyssouze), 2016 & 0.8 & 0.5 & 0.1 & 23.9 \\
\hline \multirow{3}{*}{ B2 } & Peroux (Veyle), 2015 & 1.1 & 1.1 & -0.3 & 21.3 \\
& Revel (Solnan), 2016 & 2.1 & 1.7 & 0.1 & 21.9 \\
& Dompierre (Veyle), 2010 & 2.4 & 2.2 & 0.4 & 18.2 \\
\hline
\end{tabular}

perature that is $0.96^{\circ} \mathrm{C}$ higher on average than that of the upstream region.

During the summer season, the upstream-downstream changes in the thermal regime are not well correlated with air temperature for the same periods. For example, a simple linear regression between daily maximum air temperature and $\Delta T_{\max }$ indicates that air temperature explains only $0.8 \%$ of the variability in upstream-downstream thermal regime shifts.

\subsection{Site typology}

The hierarchical cluster analysis applied to the daily summer temperature anomalies distinguished three groups.

1. A first group (A) characterized by a

- median $\Delta T_{\max }$ of less than $0.5^{\circ} \mathrm{C}$,

- median $\Delta T_{\min }$ of $+0.4-1.3^{\circ} \mathrm{C}$, and

- median $\Delta T_{\mathrm{amp}}$ of less than $-0.2^{\circ} \mathrm{C}$.

2. A second group (B1) characterized by a

- median $\Delta T_{\max }$ of $+0.6-1.2^{\circ} \mathrm{C}$ and

- median $\Delta T_{\min }$ of $+0.3-1.1^{\circ} \mathrm{C}$.

3. A third group (B2) characterized by a

- median $\Delta T_{\max }$ of greater than $1.2^{\circ} \mathrm{C}$ and

- median $\Delta T_{\min }$ of greater than $1.2^{\circ} \mathrm{C}$.

The hierarchical cluster analysis differentiates the B2 group primarily from the B1 and A groups (Fig. 6). We propose to retain the major distinction between group A and group B, because it is based on a temperature increase between upstream and downstream, not only for $T_{\min }$ (group A), but for $T_{\min }$ and $T_{\max }$ (group B), which is an important threshold for the physiology of aquatic organisms. The distribution of the differences between the minimum and maximum temperature values during summer (Fig. 5) confirms the difference among these three groups.

\subsection{Ordination results}

The first axis of the PCA analysis (74.1\% of total inertia) is correlated to all daily temperature daily anomalies, in particular to the $\Delta T_{\max }$. The second axis $(25.3 \%)$ discriminates the $\Delta T_{\text {amp }}$ with $\Delta T_{\min }$ (Fig. 6). Results of the RDA show that the water residence time and the impoundment surface explain $95.2 \%$ of the PCA structure. The projection of the sites on these axes shows a strong spreading along the first axis (Fig. 6). Additionally, the dams that had two different measurement years stay within the same range on this first axis (i.e., Fretaz and Champagne) (Fig. 6).

Multiple regression analyses between the temperature variables (median values of $\Delta T_{\min }$ and $\Delta T_{\max }$ ) and the physical characteristics obtained by the RDA (residence time and impoundment surface) resulted in high explanatory power $\left(R^{2} \approx 0.7\right)$. These regressions identified the significant contribution of residence time for $\Delta T_{\min }$ and $\Delta T_{\max }$, whereas only the surface area had a significant contribution for $\Delta T_{\max }$ (Table 4).

\subsection{Ecologically relevant intra-daily temperature variations}

To further illustrate the different thermal regime effects from our typology analysis, we compare intra-daily temperature 


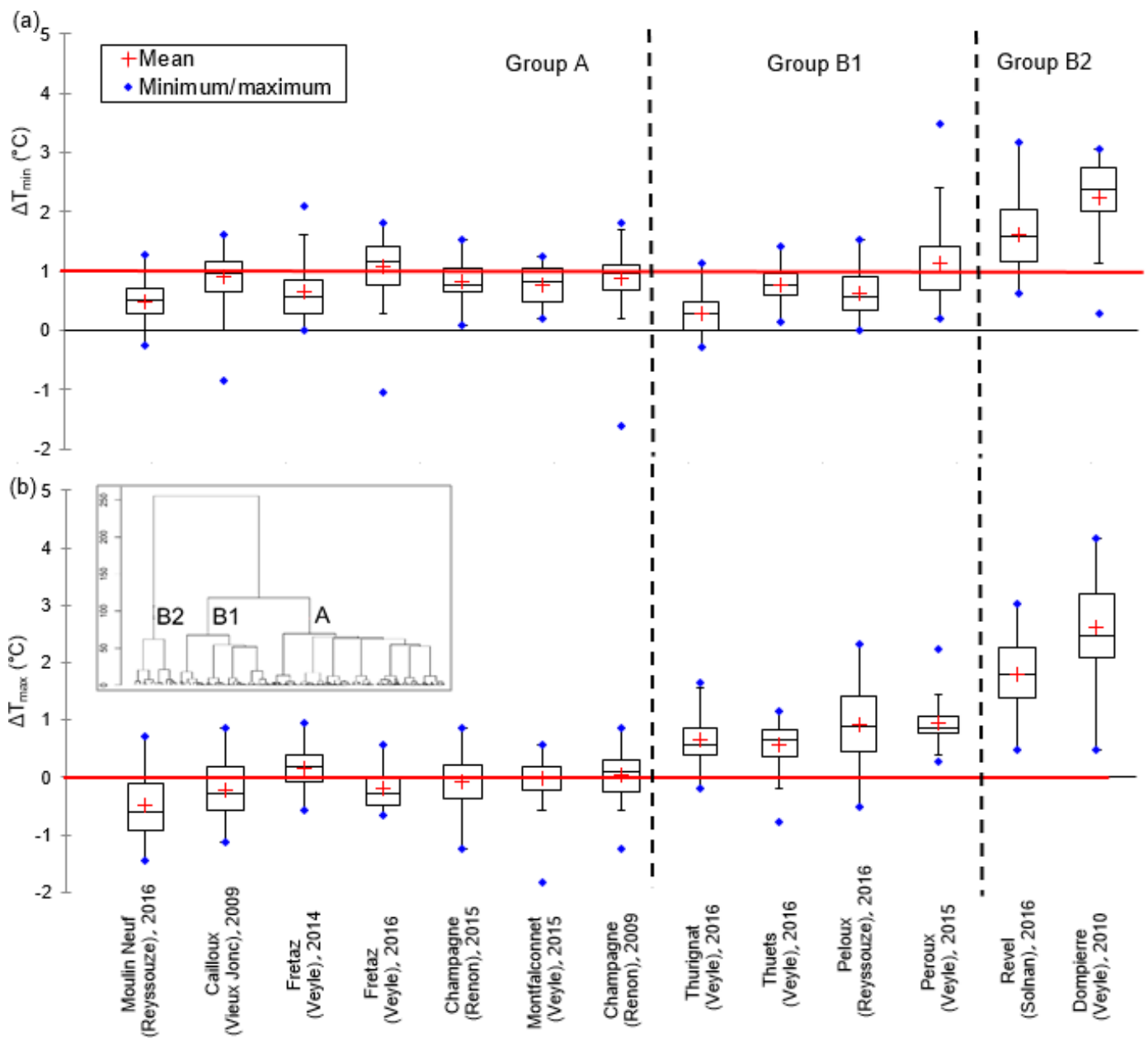

Figure 5. Box plot distribution (25\%-75\%) of upstream-downstream differences of daily (a) minimum and (b) maximum temperatures for all of the time series studied. (Red lines denote $0{ }^{\circ} \mathrm{C}$ for $\Delta T_{\max }$ and $1{ }^{\circ} \mathrm{C}$ for $\Delta T_{\min }$ and are drawn to help distinguish typologies.) The vertical dashed lines drawn in bold are the limits of the three typologies based on the hierarchical cluster analysis. Dendrogram hierarchical cluster analysis is shown as an inset.

Table 4. Results of multiple linear regressions performed on the two indicators, $\Delta T_{\min }$ and $\Delta T_{\max }$, using the dam physical characteristics surface area and residence time. Significant $p$ values are shown in bold.

\begin{tabular}{llrrr}
\hline $\begin{array}{l}\text { Dependent } \\
\text { variable }\end{array}$ & $\begin{array}{l}\text { Independent } \\
\text { variable physical } \\
\text { characteristics }\end{array}$ & $\begin{array}{r}\text { Standardized } \\
\text { coefficient }\end{array}$ & $p$ value & $R^{2}$ \\
\hline \multirow{2}{*}{$\Delta T_{\max }$} & Surface area & 0.39 & $\mathbf{0 . 0 4 1}$ & 0.72 \\
& Residence time & 0.80 & $\mathbf{0 . 0 0 1}$ & \\
\hline \multirow{2}{*}{$\Delta T_{\min }$} & Surface area & -0.13 & 0.48 & 0.68 \\
& Residence time & 0.80 & $\mathbf{0 . 0 0 1}$ & 0.68 \\
& & & &
\end{tabular}

variations for a $3 \mathrm{~d}$ time series in group A (small thermal effect) with group B (large thermal effect; Fig. 7):

- In the example of group A (Fig. 7a), the downstream thermal warming effect is limited to the nighttime $\left(T_{\min }\right)$ period (observed difference of $1^{\circ} \mathrm{C}$ warmer). Additionally, although the biological benchmark of $22^{\circ} \mathrm{C}$ is exceeded both upstream and downstream during the day on 20 August, the duration above the thermal threshold is short, preceded and followed by more favorable temperatures (i.e., the remission period).

- In contrast, in group B (Fig. 7b), the downstream temperature is systematically higher than that of the upstream region, with a temperature difference varying from +0.8 to $2.4^{\circ} \mathrm{C}$. The $22{ }^{\circ} \mathrm{C}$ threshold is exceeded downstream for a cumulative $42 \mathrm{~h}$ over the $3 \mathrm{~d}$ period. The 15 and 16 August have downstream temperatures that rarely go below $22^{\circ} \mathrm{C}$, leaving no time for thermal 


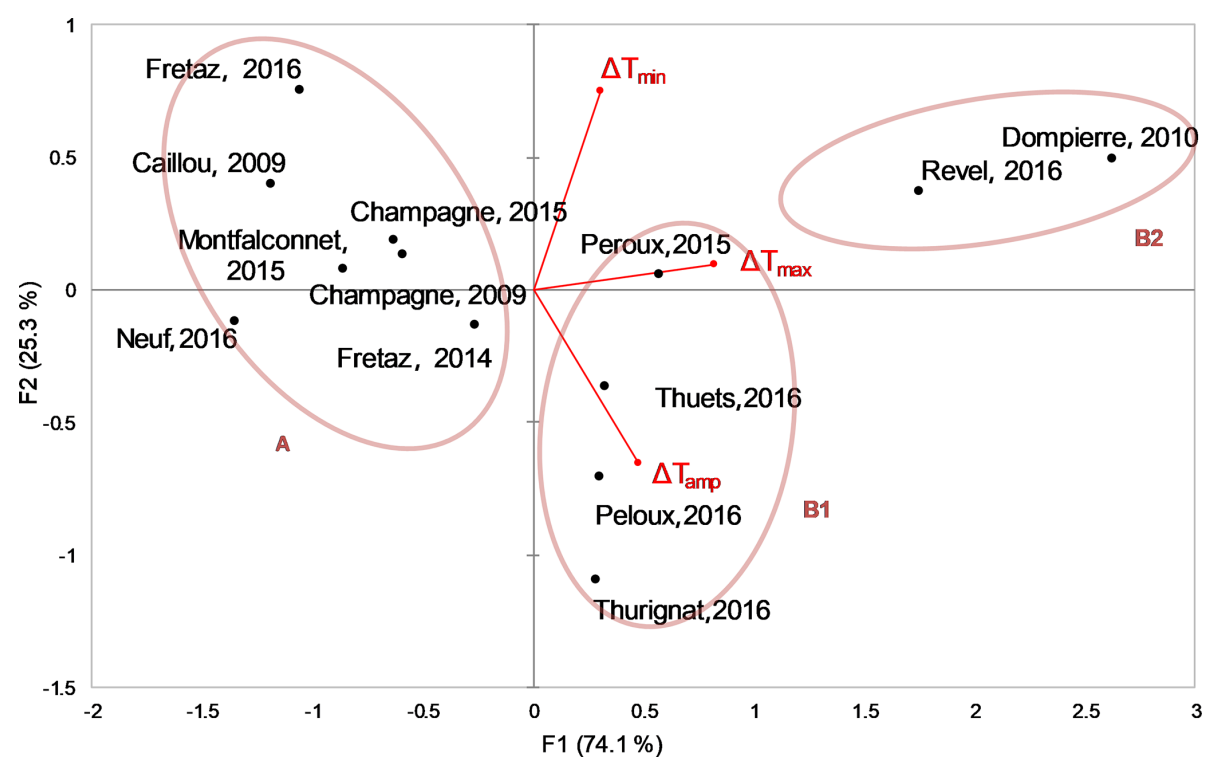

Figure 6. PCA analysis with sites plotted and temperature anomaly variables shown. Ellipses are drawn to visualize the groups obtained with the hierarchical cluster analysis.

remission (return to a temperature that is better tolerated physiologically by fish). At the same time, the upstream part of the stream is maintained at daily temperatures not exceeding this threshold.

These differences between the downstream responses in diurnal temperature variation hold throughout the time series. In other words, group A has a consistent response of no change in downstream maximum water temperatures, coupled to a consistent increase in the downstream minimum temperature (e.g., Fig. 7a). Group B differs in that the downstream maximum temperatures are also increased (e.g., Fig. 7b).

For all sites, by studying the average daily duration with a temperature continuously exceeding $22^{\circ} \mathrm{C}$, we can see the following (Fig. 8):

- downstream durations are always greater than or equal to those of the upstream durations, regardless of site typology;

- the largest upstream-downstream differences occur in the $\mathrm{B} 2$ group;

- group A is generally not affected by an upstreamdownstream increase, except for two sites which exhibit a $2 \mathrm{~h}$ increase.

\subsection{Ecologically relevant seasonal temperature variations}

We observed very similar results to our intra-daily duration analysis in our analogous study on the proportion of summer days where the maximum water temperature exceeded the threshold of $22^{\circ} \mathrm{C}$. For example, group B was much
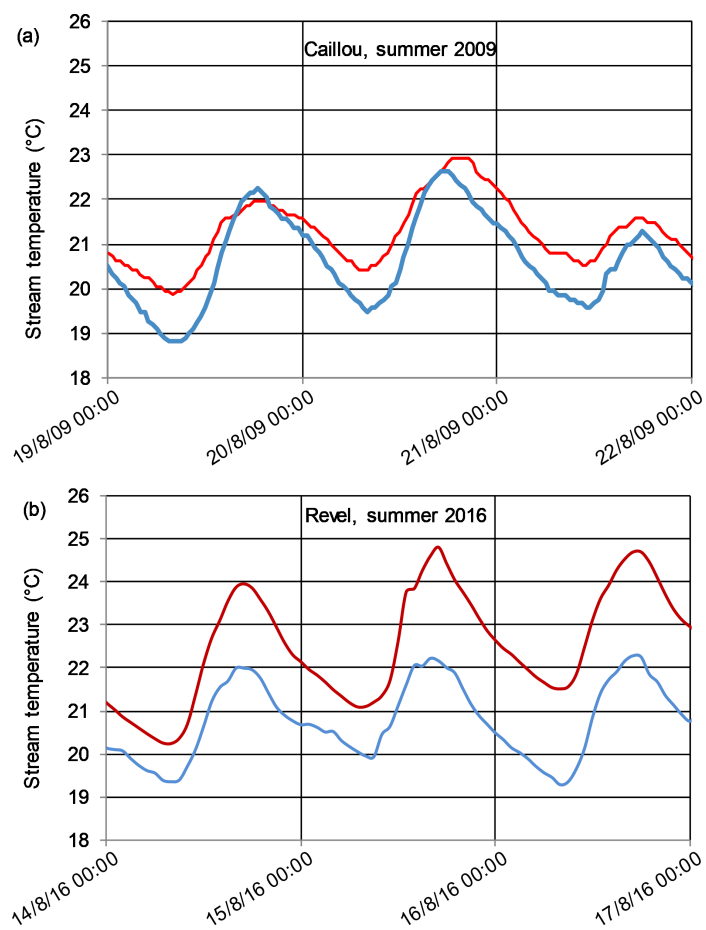

Figure 7. Time series of water temperatures upstream (blue line) and downstream (red line) of the (a) Caillou (Vieux Jonc stream) and (b) Revel (Solnan stream) dams for 3 d during August. 


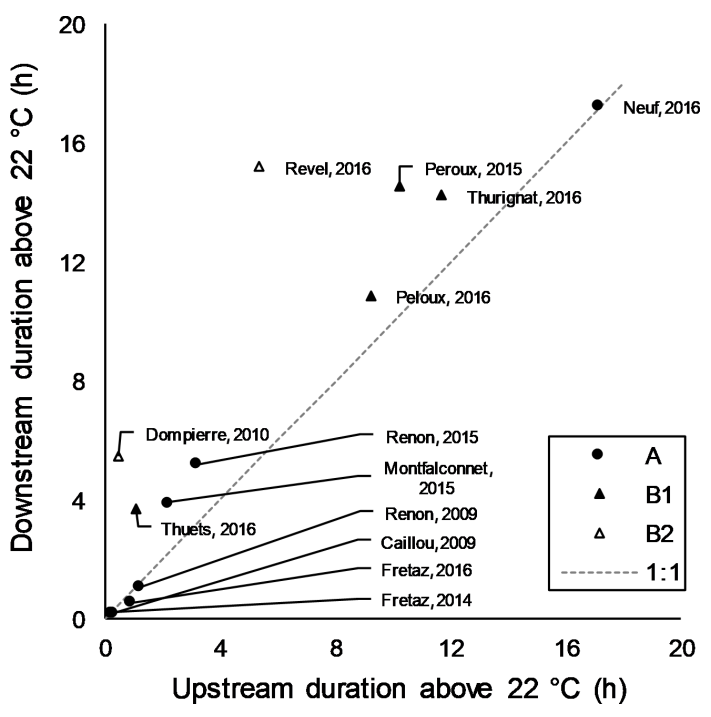

Figure 8. Mean of the daily maximum duration with a stream temperature above $22^{\circ} \mathrm{C}$, upstream and downstream of each site monitored in the study. A (circles), B1 (closed triangles), and B2 (open triangles) are the groups of sites resulting from the hierarchical cluster analysis.

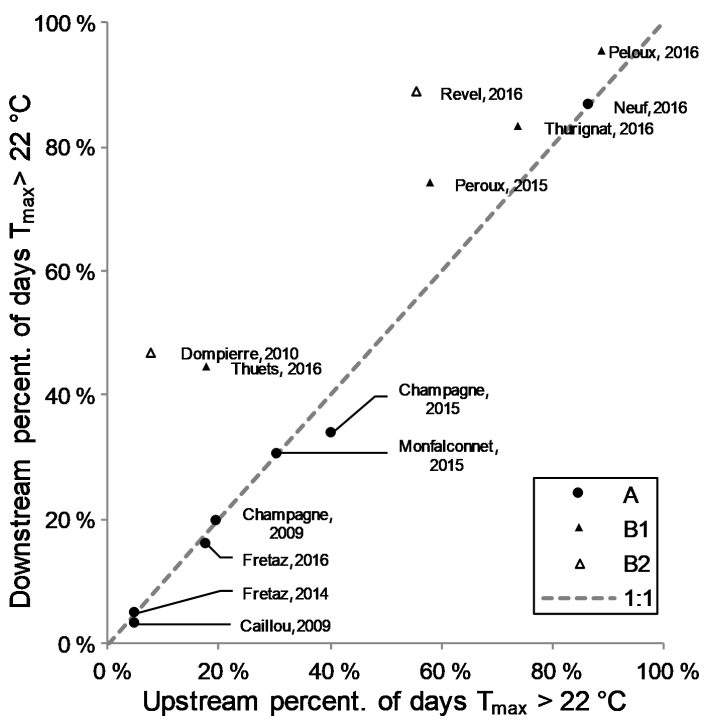

Figure 9. Percentage of the number of summer days with a diurnal maximum water temperature above $22^{\circ} \mathrm{C}$, upstream and downstream of each site monitored in the study. A (circles), B1 (filled triangles), and B2 (open triangles) are the groups of sites resulting from the hierarchical cluster analysis.

more likely to exhibit downstream increases in daily threshold exceedances (Fig. 9). Conversely, several of the group A sites had lower proportions of days where downstream daily exceedances were greater than upstream daily exceedances (i.e., Champagne 2015, Caillou 2009, Fretaz 2016).

\section{Discussion}

The number of small dams in streams is greater than the number of large dams $(>15 \mathrm{~m})$ by several orders of magnitude (Downing et al., 2006; Poff and Hart, 2002; Verpoorter et al., 2014). Despite this, small dam effects on thermal regimes are much less well known than those of large dams (Downing, 2010; Ecke et al., 2017; Smith et al., 2017). Thus, this presents a challenge with respect to identifying and generalizing the significant drivers of a realistic thermalscape (Isaak et al., 2017), which is essential for understanding the current ecological status of rivers and for predicting future changes under different climate change scenarios with sufficient realism. In addition, summertime, which has the highest temperatures, appears to potentially be the most critical period for aquatic organisms and, as such, requires special attention (Kemp et al., 2012; Zaidel, 2018).

The purpose of this study was to quantify the downstream impacts of different types of small dams on the summer water temperature in lowland streams. We investigated these effects in 11 dams across five lowland streams in the Bresse region for different climate years (12 summer time series in warmer and drier years than normal and one series in a colder and wetter year 2014; Table 2). We observed the clear influence of small dams on the downstream thermal regime at all sites: $23 \%$ of the time series exhibited a $>1{ }^{\circ} \mathrm{C}$ elevation of $T_{\max }$, and $77 \%$ of the time series exhibited $T_{\max }$ shifts -1 to $1^{\circ} \mathrm{C}$. Across all time series, the mean increase of $T_{\min }$ was $1{ }^{\circ} \mathrm{C}$. For $85 \%$ of time series, the increase in $T_{\min }$ was greater than $0.5^{\circ} \mathrm{C}$; this increase reached $2.4^{\circ} \mathrm{C}$ at certain structures (Dompierre, Fig. 6).

Our results corroborate the reviews and meta-analyses in the general trend for a small dam warming effect within a range of $0-3{ }^{\circ} \mathrm{C}$ (Lessard and Hayes, 2003; Maxted et al., 2005; Mbaka and Mwaniki, 2015; Ecke et al., 2017, 27 studies; Means, 2018, 24 sites; Zaidel, 2018, 18 sites). Occasionally, downstream warming effects reach as high as $7^{\circ} \mathrm{C}$ (Margolis et al., 2001; Carlisle et al., 2014), or 3-6 ${ }^{\circ} \mathrm{C}$ (Fraley, 1987; Lessard and Hayes, 2003, for a part of their sample; Dripps and Granger, 2013). One possible explanation is that such sites correspond to very large impoundments in comparison with low natural flows, with large areas exposed to solar radiation, which emphasizes the need for an analysis of the physical characteristics of their structures. There are also situations where the downstream temperature is lower than the upstream temperature, as we observed in one situation in our study (Moulin Neuf, Reyssouze, Fig. 6). We suggest that this phenomenon, as in the case of certain beaver dams (Majerova et al., 2015; Weber et al., 2017), occurs when the existence of a structure modifies the equilibrium conditions of the alluvial groundwater table, which under increased pressure can supply the downstream end of the structure with cooler water.

The morphology of the structures therefore appears to be of fundamental influence; impoundments with high-head dams and a small surface area would have cooler downstream 
temperatures, whereas impoundments with low-head dams and a large surface area would have warmer downstream temperatures (Fuller and Peckarsky, 2011, Rocky Mountains in Colorado; Means, 2018, upper Columbia River). We attempted to avoid possible temperature effects from alluvial groundwater by placing the downstream stations as close as possible to the dam $(<100 \mathrm{~m})$. Despite the operating precautions taken, it is possible that the Moulin Neuf site, Reyssouze, which had several secondary channels, was still influenced by groundwater inflows.

Dams in our study area also caused downstream dampening in diurnal thermal amplitudes. We observed that the daily amplitude of the downstream temperature is reduced in $61.5 \%$ of studied cases compared with that of the upstream region; this is the same proportion as noted in the observations of Zaidel (2018) for $58 \%$ of the 30 structures studied in Massachusetts. Kemp et al. (2012) also concluded that the main influence of beaver ponds was a reduction in river temperature fluctuations. Amplitude reduction is primarily due to increased daily minimum downstream temperatures (by $+0.96{ }^{\circ} \mathrm{C}$ in our study). Studying 24 beaver ponds in Washington State, Means (2018) also observed that the minimum temperature downstream was $0.8^{\circ} \mathrm{C}$ higher compared with the minimum temperature upstream.

\subsection{What physical variables are important?}

The effect of small dams on stream thermal regimes has received little attention to date, and there is still no consensus regarding which dam physical variables best predict downstream temperature patterns. Most research is focused on isolated case studies (i.e., one stream, Kornis et al., 2015; Majerova et al., 2015; Smith et al., 2017; Weber et al., 2017), and in cases where thermal measurements are secondary variables, there is often incomplete information about the physical dam characteristics (Kemp et al., 2012). Nevertheless, as early as the pioneering studies (Cook, 1940), certain dam characteristic emerged as candidate variables (e.g., exposed surface subjected to radiation and water residence time) to explain downstream shifts in thermal regime. At the same time, other commonly used dam characteristics, like dam water level and dam height, appear to be insufficient to predict a thermal effect downstream (Poff and Hart, 2002). We have described precisely these different candidate metrics for the observed sites (Table 1). Our results show that the sites can be grouped based on different behaviors for $\Delta T_{\min }, \Delta T_{\max }$, and $\Delta T_{\text {amp }}$.

We observed two distinct behaviors in upstreamdownstream thermal regime shifts in the 13 time series (Fig. 6). The first behavior, which we call group A, is characterized by an impoundment effect that reduced the downstream amplitude of the daily temperature and increased the minimum temperature (the median of $\Delta T_{\max }$ was limited to $0.3^{\circ} \mathrm{C}$ at most). The second behavior, which we call group B (split into subgroups B1 and B2), is characterized by an in- crease of both daily minimum and maximum temperatures with a corresponding change in amplitude.

We found that residence time and surface area were the principal explanatory variables of upstream-downstream temperature differences. Indeed, redundancy analysis indicated the primary differences among our site typologies were explained by these variables. For example, Group A is characterized by a short residence time (less than $0.7 \mathrm{~d}$ ) and a small impoundment surface area (less than $35500 \mathrm{~m}^{2}$ ), whereas group B is characterized either by a large surface area (greater than $35000 \mathrm{~m}^{2}$ ) with a short residence time (e.g., $0.2 \mathrm{~d}$; group B1), or by long residence times (e.g., $8.4 \mathrm{~d}$; group B2,). These physical differences are directly linked to the observed differences in thermal regime shifts. In group B2, we suggest that long residence times reduce cooling effects; the nocturnal input (i.e., the cooling effect) becomes negligible in the general heat exchange balance. However, for group B1 dams with short residence time, but large surface areas, increased energy supply by solar radiation on the larger surface may overwhelm any potential cooling effects. Multiple regression (Table 4) clarified the direction and magnitude of these effects and indicated that $\Delta T_{\max }$ is best explained by both residence time and surface area (group B effects), whereas $\Delta T_{\min }$ is best explained by only residence time (group A effects).

To summarize, we observed two primary thermal regime effects of small dams. The first group is characterized by a downstream impoundment effect that increases $T_{\min }$ and reduces $T_{\text {amp }}$, but does not significantly change $\Delta T_{\max }$ ( -0.6 to $0.3^{\circ} \mathrm{C}$ ). The second group shows downstream increases in both $T_{\min }$ and $T_{\max }$, with the little change to $\Delta T_{\mathrm{amp}}$ ( -0.3 to $0.4^{\circ} \mathrm{C}$ ). For the second group, the change in thermal regime is much clearer, with overall median $\Delta T$ differences of approximately $+0.6-2.4^{\circ} \mathrm{C}$. This clear break in the thermal regime between the upstream and downstream ecosystems was most notable during very hot periods. A larger sample of this second group type (group B) would permit a more quantitative characterization of the dams (surface area, residence time, and morphometry of the impoundment), and a possible indication of threshold values above which thermal regime shifts may emerge. One potential path forward is to create regionalized statistical models based on geographical data and dam databases, analogous to the way that ecological risk analyses are constructed (Allan et al., 2012; Van Looy et al., 2015). However, we realize that our dataset is provincial in temporal and regional extent, potentially limiting extrapolation of results to other areas with different groundwater and climatic influences.

In summary, although mean air temperature and dam height were poor predictors of daily summer temperature anomalies, residence time and surface area could clearly explain the differences in the thermal regime induced by small RRDs. These variables are candidate to generalize results to other regions. However, this generalization necessitates more 
precise information than most dam descriptions in the vast majority of available public databases.

\subsection{Analysis of the thermal regime from an ecological perspective}

The influence of dams on downstream processes varies throughout time. For example, analyses of hydrological regimes' shifts should simultaneously consider intensity, duration, frequency, seasonality, and rhythm of change (Poff et al., 1997). Ecological stresses from thermal regime shifts should account for the duration and amplitude of exposure to high temperatures and the recovery from stress during periods of lower temperature (Bevelhimer and Bennet, 2000). In this work, we examined both seasonal and intra-daily thermal effects of dams using an ecological perspective.

Shifts in downstream ecological pattern and process are dependent on the magnitude of thermal change from upstream to downstream. For fish, the literature suggests that downstream increases of approximately $2^{\circ} \mathrm{C}$ (Hay et al., 2006) or $3^{\circ} \mathrm{C}$ (Verneaux, 1977) can result in significant community shifts for many biotypologies. From this perspective, the majority of our sites belonging to groups A and B1 present a low risk with regard to the potential change in fish communities as they exhibited a moderate absolute downstream temperature increase of $0-1{ }^{\circ} \mathrm{C}$. However, the higher downstream increases of our B2 group $\left(1.2-2.4^{\circ} \mathrm{C}\right.$; Fig. 6) are likely to influence the composition of fish communities. This is especially true for certain species close to the threshold of their thermal comfort, which are often the same species already under conservation efforts. Such temperature increases can also amplify the general metabolism in the stream, possibly leading to the unwanted proliferation of algae, a less stable oxygen cycle, and stronger effects of toxic compounds (Heugens et al., 2001 in Souchon and Tissot, 2012).

On the scale of several days, it is important not to underestimate the influence of cumulative exposure to temperatures close to the maximum tolerable temperatures (Tissot and Souchon, 2010), for which the incidence of temperature variations has an impact on biological communities (Lessard and Hayes, 2003; in nine streams in Michigan, USA). In this study, we used a temperature of $22^{\circ} \mathrm{C}$ as an illustrative threshold known to be a thermal stress benchmark value for salmonids, especially for brown trout, Salmo trutta (Elliott and Elliot, 2010: upper critical incipient lethal temperature for juveniles, which is considered a very sensitive stage; Ojanguren et al., 2001: general activity of brown trout juvenile). In addition, this threshold is known to be important for the life cycle of aquatic invertebrates (Ward, 1976; Brittain and Saltveit, 1989). By looking at the fraction of time that daily maximum temperatures exceeded this threshold, we found that the majority of sites in our study area, regardless of dam structure, are unfavorable in summer for species sensitive to this threshold. Importantly, however, we found that for sites that are more favorable (e.g., Dompierre or Thuets, left side of figure), the presence of small dams induces a clear shift towards an elevated percentage of the number of days above the temperature threshold, from less than $20 \%$ upstream to more than $40 \%$ downstream.

On the daily scale, it is necessary to not only consider the maximum tolerable temperature, but also its duration of influence, as the temperature of nocturnal remission and its duration must be sufficient for organisms to repair their heat stress proteins. For example, Schrank et al. (2003) and Johnstone and Rahel (2003) suggested that daily minima provide a respite from elevated daily maximum temperatures if there is sufficient time to repair protein damage (McCullough et al., 2009). We explored this issue by calculating the average hourly duration of temperatures above the $22^{\circ} \mathrm{C}$ threshold at each site. We found that small dams more than doubled this daily threshold exceedance duration on average $(2.2 \pm 0.7$, mean $\pm \mathrm{SE}$ ), and at one site (Dompierre) increased this duration by an order of magnitude (Fig. 8). To further illustrate this effect and the differences among site typology, we presented two examples of a daily temperature regime during $3 \mathrm{~d}$ in August at the Caillou (type A) and Revel (type B2) sites (Fig. 7). At Caillou, upstream from the dam (Fig. 7a), the diel natural variation offers remission temperature for brown trout, with several hours at a temperature $<20^{\circ} \mathrm{C}$ each day. The situation is less favorable downstream with no sufficient time below this temperature. At Revel (Fig. 7b), the observed thermal daily pattern is similar, but the structure associated with group B2 exacerbated the warming of water, leading to fewer remission periods.

Without appropriate biological data, it is difficult to know how minimum and maximum water temperatures affect acclimation, performance, and stress (McCullough et al., 2009). Exploring this question may be especially relevant because small dams clearly alter stream thermal regimes. Moreover, future global warming could exacerbate these effects as it is expected to increase daily minimum temperatures more than daily maximum temperatures, with a corresponding decrease in the diurnal temperature range and an increase in mean daily temperature (Easterling et al., 1997; Vose et al., 2005).

\subsection{Diversity of situations}

We measured variable warming effects according to a diversity of situations present within a relatively modest geographical area $\left(2025 \mathrm{~km}^{2}\right)$, subjected to the same climate. We suggest that based on the downstream warming effects we observed, and because of the high density of dams in the landscape $(0.64$ per $\mathrm{km})$, the thermal landscape of this region is potentially fragmented. In other words, we expect that small dams in this region create a discontinuous distribution of stream thermal regimes throughout the river network. However, we acknowledge that to have a realistic thermal landscape, where ecological dynamics can be predicted 
in the long term, it is necessary to account for additional features than we have done here. For example, it is important to consider the effects of unshaded versus shaded river reaches, which influence radiation warming effects, and the spatial distributions of groundwater inflows, which provide cooling effects. We note that regardless of application, using air temperature to predict water temperature at the daily scale should be used with caution (see Sect. 3.2).

Our work highlights physical dam characteristics that could be useful in a large-scale heat risk analysis, or in modeling scenarios aiming to account for changes in thermal regimes. For example, a simple model using only a small dam residence time and surface area may be able to diagnose thermal regime change at the regional scale with sufficient accuracy. Moreover, the results presented here could also provide essential guidance to environmental protection authorities in their prioritization of rivers to be protected or restored, especially for those rivers that require greater thermal resilience.

Given the complexity and high variability of the river systems encountered in this study (Strahler orders spanning 35), it seems essential to us (and see Isaak et al., 2017, 2018; Steel et al., 2017; Dzara et al., 2019) to continue to conduct and expand well targeted stream temperature monitoring. This type of monitoring is requisite before being able to model stream temperature with sufficient spatial and temporal resolution. Modeling these systems accurately is a major challenge, because these aquatic spaces will undergo major thermal and hydrological alteration with climate change, where tipping points in biotic distributions are likely to occur.

\section{Conclusions}

We quantified the impact of small dams on the temperature of streams, and identified major drivers of these impacts, adding to a current paucity of information on this topic in the scientific literature. Our unique interannual, cross-site analysis of summer stream temperatures showed that contemporary dam impacts are already ecologically significant to downstream reaches, and these effects may be exacerbated by expected warming in the study area (see IPCC scenarios of global change for Val de Saone). We identified the primary drivers of the temperature regime responses as residence time and the impoundment surface area. The influence of these drivers in other landscapes needs to be confirmed by other datasets that are not yet well developed or accessible.

Code and data availability. Code, spreadsheets, and data used in this work are available upon request from the authors.
Author contributions. AC, KVL, and YS designed the field study and $\mathrm{AC}$ conducted it. JSD conducted the stream temperature duration threshold analysis and provided critical review/editing of the paper and figures. All authors contributed to the paper preparation.

Competing interests. The authors declare that they have no conflict of interest.

Acknowledgements. We thank the three anonymous referees who made it possible to improve the text. We also thank the local river management body, the Syndicat Mixte Veyle Vivante and its employees Laurent Charbonnier and Stéphane Kihl, for installing the measurement network, for their help with field monitoring, and for their valuable practical advice. Furthermore, we are grateful for the punctual gauging data (edition of 15 April 2002) provided by the regional branch of the Ministry of the Environment (Dreal RhôneAlpes; formerly DIREN SEMA). The Rhone Mediterranean Corsica Water Agency provided financial support which allowed the times series to be recorded and the data to be analyzed. Jacob Diamond is supported by POI FEDER Loire n²017-EX001784, the Water Agency of Loire Catchment AELB, and the University of Tours.

Review statement. This paper was edited by Anas Ghadouani and reviewed by three anonymous referees.

\section{References}

Allan, J. D. and Castillo, M. M.: Stream Ecology. Structure and Function of Running Waters, 2nd Edn., Springer, Dordrecht, the Netherlands, 436 pp., 2007.

Allan, J. D., Yuan, L. L., Black, P., Stockton, T. O. M., Davies, P. E., Magierowski, R. H., and Read, S. M.: Investigating the relationships between environmental stressors and stream condition using Bayesian belief networks, Freshwater Biol., 57, 58-73, 2012.

Bernhardt, E. S., Heffernan, J. B., Grimm, N. B., Stanley, E. H., Harvey, J., Arroita, M., Appling, A., Cohen, M., McDowell, W. H., and Hall, R.: The metabolic regimes of flowing waters, Limnol. Oceanogr., 63, S99-S118, 2018.

Bevelhimer, M. and Bennett, W.: Assessing cumulative thermal stress in fish during chronic intermittent exposure to high temperatures, Environ. Sci. Policy, 3, 211-216, 2000.

Brett, J. R. and Groves, T. D. D.: Physiological energetics, in: Fish Physiology, Vol. 8, edited by: Hoar, W. S., Randall, D. J., and Brett, J. R., Academic Press, New York, 279-352, 1979.

Brittain, J. E. and Saltveit, S. J.: A review of the effect of river regulation on mayflies (Ephemeroptera), Regulat. Rivers: Res. Manage., 3, 191-204, 1989.

Brown, J. H., Gillooly, J. F., Allen, A. P., Savage, V. M., and West, G. B.: Toward a metabolic theory of ecology, Ecology, 85, 17711789, 2004.

Caissie, D.: The thermal regime of rivers: a review, Freshwater Biol., 51, 1389-1406, https://doi.org/10.1111/j.13652427.2006.01597.x, 2006. 
Carlisle, D. M., Nelson, S. M., and Eng, K.: Macroinvertebrate community condition associated with the severity of streamflow alteration, River Res. Appl., 30, 29-39, https://doi.org/10.1002/rra.2626, 2014.

Cook, D. B.: Beaver-trout relations, J. Mammal., 21, 397-401, 1940

Coutant, C.: Thermal preference: when does an asset become a liability?, Environ. Biol. Fish., 18, 161-172, 1987.

Cumming, G. S.: The impact of low-head dams on fish species richness in Wisconsin, USA, Ecol. Appl., 14, 1495-1506, 2004.

Downing, J. A.: Emerging global role of small lakes and ponds: little things mean a lot, Limnetica, 29, 9-24, 2010.

Downing, J. A., Prairie, Y. T., Cole, J. J., Duarte, C. M., Tranvik, L. J., Striegl, R. G., McDowell, W. H., Kortelainen, P., Caraco, N. F., Melack, J. M., and Middelburg, J. J.: The global abundance and size distribution of lakes, ponds, and impoundments, Limnol. Oceanogr., 51, 2388-2397, https://doi.org/10.4319/lo.2006.51.5.2388, 2006.

DREAL - Direction Regionale de l'Environnement, de l'Amenagement et du Logement: Bulletins hydrologiques de la région Auvergne-Rhône-Alpes, available at: http://www.auvergne-rhone-alpes.developpement-durable. gouv.fr/hydrometrie-r3157.html, last access: 20 April 2018.

Dripps, W. and Granger, S. R.: The impact of artificially impounded, residential headwater lakes on downstream water temperature, Environ. Earth Sci., 68, 2399-2407, https://doi.org/10.1007/s12665-012-1924-4, 2013.

Dunham, J. B., Chandler, G. L., Rieman, B. E., and Martin, D.: Measuring stream temperature with digital data loggers: A user's guide, Gen. Tech. Rep. RMRSGTR-150WWW, Department of Agriculture, Forest Service, Rocky Mountain Research Station, Fort Collins, CO, USA, 15 pp., 2005.

Dzara, J. R., Neilson, B. T., and Null, S. E.: Quantifying thermal refugia connectivity by combining temperature modeling, distributed temperature sensing, and thermal infrared imaging, Hydrol. Earth Syst. Sci., 23, 2965-2982, https://doi.org/10.5194/hess-23-2965-2019, 2019.

Easterling, D. R., Horton, B., Jones, P. D., Peterson, T. C., Karl, T. R., Parker, D. E., Salinger, M. J., Razuvayev, V., Plummer, N., and Jamason, P.: Maximum and minimum temperature trends for the globe, Science, 277, 364-367, 1997.

Ecke, F., Levanoni, O., Audet, J., Carlson, P., Eklöf, K., Hartman, G., McKie, B., Ledesma, J., Segersten, J., and Truchy, A.: Meta-analysis of environmental effects of beaver in relation to artificial dams, Environ. Res. Lett., 12, 113002, https://doi.org/10.1088/1748-9326/aa8979, 2017.

Elliott, J. M. and Elliott, J. A.: Temperature requirements of Atlantic salmon Salmo salar, brown trout Salmo trutta and Arctic charr Salvelinus alpinus: predicting the effects of climate change, J. Fish Biol., 77, 1793-1817, https://doi.org/10.1111/j.10958649.2010.02762.x, 2010.

Ellis, L. E. and Jones, N. E.: Longitudinal trends in regulated rivers: a review and synthesis within the context of the serial discontinuity concept, Environ. Rev., 21, 136-148, https://doi.org/10.1139/er-2012-0064, 2013.

Fraley, J. J.: Effects of elevated stream temperatures below a shallow reservoir on a cold water macroinvertebrate fauna, in: The ecology of regulated streams, edited by: Ward, J. V. and Stanford, J. A., Plenum Press, New York, London, 257-272, 1987.
Fuller, M. R. and Peckarsky, B. L.: Ecosystem engineering by beavers affects mayfly life histories, Freshwater Biol., 56, 969979, 2011.

Hannah, D. M., Malcolm, I. A., Soulsby, C., and Youngson, A. F.: Heat exchanges and temperatures within a salmon spawning stream in the Cairngorms, Scotland: seasonal and sub-seasonal dynamics, River Res. Appl., 20, 635-652, https://doi.org/10.1002/rra.771, 2004.

Hay, J., Hayes, J. W., and Young, R. G.: Water quality guidelines to protect trout fishery values, Cawthron Institute, Nelson, New Zealand, 2006.

Hayes, D. B., Dodd, H., and Lessard, J.: Effects of small dams on coldwater stream fish communities, in: American Fisheries Society Symposium, 25-26 August 2004, Bethesda, Maryland, USA, 587-602, 2008.

Hester, E. T., Doyle, M. W., and Poole, G. C.: The influence of in-stream structures on summer water temperatures via induced hyporheic exchange, Limnol. Oceanogr., 54, 355-367, 2009.

Hester, E. T. and Doyle, M. W.: Human Impacts to River Temperature and Their Effects on Biological Processes: A Quantitative Synthesis, J. Am. Water Resour. Assoc., 47, 571-587, https://doi.org/10.1111/j.1752-1688.2011.00525.x, 2011.

Heugens, E. H., Hendriks, A. J., Dekker, T., v. Straalen, N. M., and Admiraal, W.: A review of the effects of multiple stressors on aquatic organisms and analysis of uncertainty factors for use in risk assessment, Crit. Rev. Toxicol., 31, 247-284, 2001.

ICOLD - International Commission on Large Dam: Number of Dams by Country Members, available at: http://www. icold-cigb.org/GB/world_register/general_synthesis.asp, last access: 20 April 2018

IPCC: Climate Change 2007: The Physical Science Basis, in: Contribution of Working Group I to the Fourth Assessment Report of the Intergovernmental Panel on Climate Change, 996 pp., 2007.

IPCC: Climate Change 2013: The Physical Science Basis, in: Contribution of Working Group I to the Fifth Assessment Report of the Intergovernmental Panel on Climate Change, 1535 pp., 2013.

Isaak, D. J., Wenger, S. J., and Young, M. K.: Big biology meets microclimatology: defining thermal niches of ectotherms at landscape scales for conservation planning, Ecol. Appl., 27, 977-990, 2017.

Isaak, D. J., Luce, C. H., Horan, D. L., Chandler, G. L., Wollrab, S. P., and Nagel, D. E.: Global Warming of Salmon and Trout Rivers in the Northwestern U.S.: Road to Ruin or Path Through Purgatory?, T. Am. Fish. Soc., 147, 566-587, https://doi.org/10.1002/tafs.10059, 2018.

Johnstone, H. C. and Rahel, F. J.: Assessing temperature tolerance of Bonneville cutthroat trout based on constant and cycling thermal regimes, T. Am. Fish. Soc., 132, 92-99, 2003.

Kelleher, C., Wagener, T., Gooseff, M., McGlynn, B., McGuire, K., and Marshall, L.: Investigating controls on the thermal sensitivity of Pennsylvania streams, Hydrol. Process., 26, 771-785, https://doi.org/10.1002/hyp.8186, 2012.

Kemp, P. S., Worthington, T. A., Langford, T. E., Tree, A. R., and Gaywood, M. J.: Qualitative and quantitative effects of reintroduced beavers on stream fish, Fish Fisher., 13, 158-181, 2012.

Kornis, M. S., Weidel, B. C., Powers, S. M., Diebel, M. W., Cline, T. J., Fox, J. M., and Kitchell, J. F.: Fish community dynamics following dam removal in a fragmented agricultural stream, 
Aquat. Sci., 77, 465-480, https://doi.org/10.1007/s00027-0140391-2, 2015.

Lessard, J. L. and Hayes, D. B.: Effects of elevated water temperature on fish and macroinvertebrate communities below small dams, River Res. Appl., 19, 721-732, 2003.

Majerova, M., Neilson, B. T., Schmadel, N. M., Wheaton, J. M., and Snow, C. J.: Impacts of beaver dams on hydrologic and temperature regimes in a mountain stream, Hydrol. Earth Syst. Sci., 19, 3541-3556, https://doi.org/10.5194/hess-19-3541-2015, 2015.

Margolis, B. E., Castro, M. S., and Raesly, R. L.: The impact of beaver impoundments on the water chemistry of two Appalachian streams, Can. J. Fish. Aquat. Sci., 58, 2271-2283, 2001.

Maxted, J. R., McCready, C. H., and Scarsbrook, M. R.: Effects of small ponds on stream water quality and macroinvertebrate communities, New Zealand, J. Mar. Freshw. Res., 39, 1069-1084, 2005.

Mbaka, J. G. and Mwaniki, W. M.: A global review of the downstream effects of small impoundments on stream habitat conditions and macroinvertebrates, Environ. Rev., 23, 257-262, 2015.

McCullough, D. A., Bartholow, J. M., Jager, H. I., Beschta, R. L., Cheslak, E. F., Deas, M. L., Ebersole, J. L., Foott, J. S., Johnson, S. L., Marine, K. R., Mesa, M. G., Petersen, J. H., Souchon, Y., Tiffan, K. F., and Wurtsbaugh, W. A.: Research in thermal biology: Burning questions for coldwater stream fishes, Rev. Fish. Sci., 17, 90-115, 2009.

Means, C.: Stream temperature variability in headwater beaver dam complexes in relation to hydrologic and environmental factors, MS thesis, Univerity of Washington, Washington, USA, 48 pp., 2018.

Mohseni, O., Stefan, H. G., and Erickson, T. R.: A nonlinear regression model for weekly stream temperatures, Water Resour. Res., 34, 2685-2692, https://doi.org/10.1029/98WR01877, 1998.

Ojanguren, A. F., Reyes-Gavilán, F. G., and Braña, F.: Thermal sensitivity of growth, food intake and activity of juvenile brown trout, J. Therm. Biol., 26, 165-170, 2001.

O'Keeffe, J. H., Palmer, R. W., Byren, B. A., and Davies, B. R.: The effects of impoundment on the physicochemistry of two contrasting southern African river systems, River Res. Appl., 5, 97-110, 1990.

Olden, J. D. and Naiman, R. J.: Incorporating thermal regimes into environmental flows assessments: Modifying dam operations to restore freshwater ecosystem integrity, Freshwater Biol., 55, 86107, 2010.

Peings, Y., Jamous, M., Planton, S., Le Treut, H., Déqué, M., Gallée, H., and Li, L.: Scénarios régionalisés-Indices de référence pour la métropole, Ministère de l'Écologie, du Développement durable, des Transports et du Logement, Paris, 2012.

Poff, N. L. and Hart, D. D.: How dams vary and why it matters for the emerging science of dam removal, Bioscience, 52, 659-668, 2002.

Poff, N. L., Allan, J. D., Bain, M. B., Karr, J. R., Prestegaard, K. L., Richter, B. D., Sparks, R. E., and Stromberg, J. C.: The natural flow regime. A paradigm for river conservation and restoration, BioScience, 47, 769-784, 1997.

Rader, R. B., Voelz, N. J., and Ward, J. V.: Post-flood recovery of a macroinvertebrate community in a regulated river: resilience of an anthropogenically altered ecosystem, RestorationEcology,
16, 24-33, https://doi.org/10.1111/j.1526-100X.2007.00258.x, 2007.

Schrank, A. J., Rahel, F. J., and Johnstone, H. C.: Evaluating laboratory-derived thermal criteria in the field: an example involving Bonneville cutthroat trout, T. Am. Fish. Soc., 132, 100109, 2003.

Sigourney, D. B., Letcher, B. H., and Cunjak, R. A.: Influence of Beaver Activity on Summer Growth and Condition of Age-2 Atlantic Salmon Parr, T. Am. Fish. Soc., 135, 1068-1075, 2006.

Smith, S. C. F., Meiners, S. J., Hastings, R. P., Thomas, T., and Colombo, R. E.: Low-Head Dam Impacts on Habitat and the Functional Composition of Fish Communities, River Res. Appl., 33, 680-689, https://doi.org/10.1002/rra.3128, 2017.

Souchon, Y. and Tissot, L.: Synthesis of Thermal Tolerances of the Common Freshwater Fish Species in Large Western Europe Rivers, Knowledge and Management of Aquatic Ecosystems, EDPsciences/ONEMA, 405, 48, https://doi.org/10.1051/kmae/2012008, 2012.

Steel, E., Beechie, T., Torgersen, C., and Fullerton, A.: Envisioning, Quantifying, and Managing Thermal Regimes on River Networks, BioScience, 67, 506-522, https://doi.org/10.1093/biosci/bix047, 2017.

Ter Braak, C. J. F.: Canonical correspondence analysis: a new eigenvector technique for multivariate direct gradient analysis, Ecology, 67, 1167-1179, 1986.

Tissot, L. and Souchon, Y.: Synthèse des tolérances thermiques des principales espèces de poissons des rivières et fleuves de plaine de l'ouest européen, Hydroécol. Appl., 17, 17-76, https://doi.org/10.1051/hydro/2010004, 2010.

Van Looy, K., Piffady, J., Tormos, T., Villeneuve, B., Valette, L., Chandesris, A., and Souchon, Y.: Unravelling River System Impairments in Stream Networks with an Integrated Risk Approach, Environ. Manage., 55, 1343-1353, 2015.

Verneaux, J.: Biotypologie de l'écosystème “eau courante". Déterminisme approché de la structure biotypologique, Comptes Rendus de l'Académie des Sciences de Paris, 284, 77-80, 1977.

Verpoorter, C., Kutser, T., Seekell, D. A., and Tranvik, L. J.: A global inventory of lakes based on high-resolution satellite imagery, Geophys. Res. Lett., 41, 6396-6402, 2014.

Vose, R. S., Easterling, D. R., and Gleason, B.: Maximum and minimum temperature trends for the globe: An update through 2004, Geophys. Res. Lett., 32, L23822, https://doi.org/10.1029/2005GL024379, 2005.

Ward Jr., J. H.: Hierarchical Grouping to Optimize an Objective Function, J. Am. Stat. Assoc., 58, 236-244, 1963.

Ward, J. V.: Effects of flow patterns below large dams on stream benthos: a review, in: Instream flow needs symposium, edited by: Orsborne, J. F. and Allman, C. H., American Fisheries Society, Bethesda, Maryland, USA, 235-253, 1976.

Ward, J. V. and Stanford, J. A.: The serial discontinuity concept of lotic ecosystems, in: Dynamics of lotic ecosystems, edited by: Fontaine, T. D. and Bartell, S. M., Ann Arbor Science, Ann Arbor, Michigan, 29-42, 1983.

Wasson, J. G., Chandesris, A., Pella, H., and Blanc, L.: Typology and reference conditions for surface water bodies in France: the hydro-ecoregion approach, TemaNord, 566, 37-41, 2002.

Webb, B. W., Hannah, D. M., Moore, R. D., Brown, L. E., and Nobilis, F.: Recent advances in stream and river temperature research, Hydrol. Process., 22, 902-918, 2008. 
Weber, N., Bouwes, N., Pollock, M. M., Volk, C., Wheaton, J. M., Wathen, G., Wirtz, J., and Jordan, C. E.: Alteration of stream temperature by natural and artificial beaver dams, PLOS ONE, 12, e0176313, https://doi.org/10.1371/journal.pone.0176313, 2017.

WMO: International meteorological vocabulary, No. 182, TP. 91, Pp. xvi, 276, Sw. fr. 40, Secretariat of the World Meteorological Organization, Geneva, 1966.
Woodward, G., Perkins, D. M., and Brown, L. E.: Climate change and freshwater ecosystems: Impacts across multiple levels of organization, Philos. T. Roy. Soc. B, 365, 2093-2106, 2010.

Zaidel, P.: Impacts of Small, Surface-Release Dams on Stream Temperature and Dissolved Oxygen in Massachusetts, University of Massachusetts, Amherst, 283 pp., 2018. 